\title{
THE OTTOMAN-CROATIAN BORDER AT THE END OF THE MIDDLE AGES ${ }^{*}$
}

\section{Borislav Grgin}

Faculty of Humanities and Social Sciences, University of Zagreb

\section{ABSTRACT}

In this paper the attempt is made to analyze the Croatian-Ottoman relations in the period from 1458 to 1527, from the points of view of armed conflicts, negotiations, processes of migration, exchange of goods and ideas and various forms of symbolic selfrepresentation and images of the heathen Other.

It is often the case that historical research reflects preoccupations, questions, dilemmas and uncertainties of our own time. The 2015 wave of refugees from the Syrian conflict and the intensification of terrorist attacks in Europe, inspired by radical Islamism, profoundly shook many European countries and brought once again onto surface old prejudices, stereotypes and fears of the unknown. Once again the troubled historical relations between Europe and the Middle East, between the world of Christianity and the world of Islam, became the political agenda of the day, the same like after the great commotion created by the $9 / 11$ attacks. On the other hand, the political agenda that is shaping the political landscape in today's Turkey has its reflections even in this region of Europe. In this context, even the role of autochthonous Balkan Muslim population is being reevaluated and reexamined from various sides, aspects and perspectives, both on the regional and on the European level.

In this context, the Ottoman conquest of Southeastern and parts of Central Europe during the Late Middle Ages and the Early Modern Period inevitably attracts the renewed interest of scholars, as well as of the wider public, particularly in this part of the world. The questions how, why, with which consequences etc. the abovementioned conquest happened, once again attract attention. Therefore, following this path, the attempt will be made here to cast light on a small, but important part of territories between the Christian and the Muslim worlds in the Late Middle Ages, the Croatian-Ottoman border. I will try to analyze several questions. In which context did the Ottoman-Croatian border emerge and how it changed through time till 1527 ? What kind of border it was? Was it an impenetrable barrier

This paper has been presented at the conference Between Three Seas: Borders, Migrations, Connections. The Third Biennial Conference of the Medieval Central Europe Research Network. The conference was held in Zagreb, in April 2018. 
or a fluid and only occasionally sealed obstacle? Did it prevent the transfer of people, ideas, goods and information from one side to the other? Besides this, I would like to raise the question of symbolical significance of the border in question. For the contemporaries on both sides, was this border primarily perceived as border between states, religions, ethnical or national groups, or civilizations?

The analysis covers the period between 1458 and 1527 and it focuses on medieval Croatia, south of the Kupa and Sava rivers. This is the territory that experienced significant demographic and economic losses during the period in question. Usually it was, and mainly still is, perceived in Croatian historiography as a period of collapse of all medieval social and economic structures, coupled with demographic catastrophe. This overall evaluation was to a certain degree strengthened through research done in the last few decades. ${ }^{1}$ On the other hand, some younger Croatian experts of Ottoman studies put these assumptions partly under the question mark. ${ }^{2}$

Although the first Ottoman incursions into medieval Croatian lands occurred already in the second decade of the $15^{\text {th }}$ century during the reign of King Sigismund (1387-1437), only after the conquest of medieval Bosnia, in 1463, the Ottomans became Croatian immediate neighbors. This fact significantly altered the strategic position of medieval Dalmatia, Croatia and Slavonia. The Ottomans started with their regular plundering and pillaging of neighboring regions, from 1465 onwards, on an almost yearly basis. After the formation of the Captaincy of Senj, in 1469, the Hungarian and Croatian border defense system, initiated already by King Sigismund, finally became fully operational in its Croatian part. In this area, from Jajce in Bosnia it stretched till Klis, in the immediate hinterland of Split in the south, and till Senj on the Adriatic coast in the west. This system consisted of two parallel lines of fortresses. ${ }^{3}$ Later even the Ottomans gradually started to build an analogue system of fortresses on their side of the border. Despite the constant skirmishes and

See primarily Ivan Jurković, "Migracije. Raseljenička kriza za osmanske ugroze: "U bašćini mojoj ne dadu mi priti «, in Vrijeme sazrijevanja, vrijeme razaranja: Hrvatske zemlje u kasnome srednjem vijeku, ed. Marija Karbić (Zagreb: Matica hrvatska. 2019), 99-100; idem, "Šesnaestostoljetna hrvatska raseljenička kriza i moderna sociološka terminologija," Društvena istraživanja 14, nos. 4-5 (2005): 762-764.; idem, "Klasifikacija hrvatskih raseljenika za trajanja osmanske ugroze (od 1463. do 1593.)," Migracijske i etničke teme 19, nos. 2-3 (2003): 147-149, 165-166.

2 Kornelija Jurin Starčević, “Osmanski krajiški prostor: rat i društvo u jadransko-dinarskom zaleđu u 16. i 17. stoljeću” (PhD diss., University of Zagreb, 2012), passim; idem, "Srednjodalmatinsko zaleđe za vrijeme osmanske vladavine u 16. i 17. stoljeću " (MrSc diss., University of Zagreb, 2005), passim; idem, "Demografska kretanja u selima srednjodalmatinskog zaleđa u 16. i početkom 17. stoljeća prema osmanskim detaljnim poreznim popisima (mufassal defterima), “ Prilozi za orijentalnu filologiju 54 (2005): 139.

3 Ferenc Szakály, “The Hungarian-Croatian Border Defense System and its Collapse," in War and Society in Late Medieval and Early Modern Hungary (War and Society in Eastern Central Europe, Vol. 3), eds. János M. Bak and Béla K. Király (Brooklyn: Brooklyn College Press. 1982), 141143. 
devastating raids, occasional fighting and real wars, and even several real pitched battles, the balance of power on this segment of the frontier remained mainly unaltered until the second decade of the sixteenth century. However, already during the reign of Sultan Selim (1512-1520), before Suleyman's great conquests during the 1520's, the Croatian part of the border defense system started to collapse, due to poor maintenance, lack of resources or substantial help from the central authorities or abroad, from the neighboring Christian powers - Venice, papacy and the Empire. During the last years preceding the Mohács battle, all that was left of medieval Croatia was mainly the territory around the vital communication between Senj and Zagreb and the surrounded and isolated outpost of Klis in the south. On the other hand, till 1527 the Venetians mainly managed to preserve the Dalmatian coastal towns with their narrow districts in the hinterland, while the Ottomans conquered the bulk of former medieval Croatian territories there, too. Therefore in the long run, taking the whole analyzed period into account, the Ottomans significantly altered the political map of the whole region, coupled with radical changes in political, social, judicial and economic structures in the conquered regions.

One should not, however, imagine the Croatian-Ottoman volatile and changeable border of that time as something even remotely close to our contemporary notion of state borders. It is well known fact that pre-modern states in general were not able to exercise territorial and border control to an extent that the modern and contemporary states can. This was true even in our case, when the border was divided between two worlds in permanent conflict of low intensity. The Hungarian and Croatian border defense system relied on fortresses, located on strategically chosen places, and on natural obstacles, great rivers, mountains and like. However, wide areas in between those regions were practically defenseless, where both sides exercised very little or no control at all. These huge portions terrae nullius were, in fact, offering to both sides on the frontier a good chance to launch skirmishes, raids, pillaging and plundering, occasionally deep into the enemy's hinterland and causing significant damage, particularly from the Ottomans to the Christian side. However, at least during Matthias's reign (1458-1490), even the Christian side still occasionally had the power to retaliate.

The Croatian defense system was, of course, still typically medieval, essentially static, and in the long run it was no match for the advancing Ottomans. Even in Croatian case the Ottomans applied, like in many cases before and after that on the territories of their adversaries, their proven and successful military doctrine of raising everything down to the ground via repeated raiding campaigns throughout a prolonged period of time. Therefore, the defense potentials of their Christian adversaries were constantly being weakened. The resources for the upkeep and maintenance of the fortresses, local magnates, nobility and peasant population were gradually diminishing, year by year. This, in turn, led to ever increased emigration 
from the endangered zones that, in turn, further weakened the defensive potentials of the Christian side. Such circulus vitiosus showed its devastating effects only after a longer period of time. In Croatian case, as it was stated above, only during the second and third decades of the sixteenth century. On the other hand, the serious negative consequences were noticeable in central Croatia already at the end of Matthias's reign. For example, the famous urbarium of Modruš, estate of the most important branch of the Frankapani counts at that time, reflects already in 1486 a significant degree of depopulation and various economic and other problems of upkeep of the estate as a functioning unit, caused by the Ottomans up till then. ${ }^{4}$

However fragmentary and in many cases one-sided, relevant sources both on Croatian and on the Ottoman side of the border indicate that the border in question did not mean an impenetrable obstacle to various forms of exchange. This is valid most of all for the exchange of information and political contacts even on a higher level. Sources of that time, particularly on the Christian side, mention various instances of negotiations with the Ottomans about possible switching sides and acceptance of sultan's suzerainty. The accusations of such nature were not rare among Croatian and Slavonian magnates at the time. We know now that some of the last Kurjakovići counts of Krbava (Corbavia) seemingly accepted to switch sides, while at the same time keeping their ties with the Venetians. ${ }^{5}$ On the other hand, the same request that the Ottomans addressed to Count Bernardin Frankapan, in 1494, did not have any success; although these requests were coupled with concrete menaces against Bernardin's vital interests in the case of refusal. ${ }^{6}$ It has to be emphasized that this topic has not been thoroughly researched up till now. One of the possible reasons for that was the reluctance of traditional historians in Croatia to deal with such typical pre-modern phenomena. Namely, the attitude of the Kurjakovići did not fit into the national grand narrative of antemurale Christianitatis that was an important element of the ever growing nationalist ideology. Therefore, such behavior was usually too easily dismissed as mutual slender campaign among the Christian potentates, with the scope to weaken the adversaries and rivals among the fellow magnates and nobles. On the other hand, taken their historical context into consideration, such agreements with the Ottomans were more than probable. On the other hand, it does not mean that at this period such agreements were irrevocable or permanent, and they did not resemble the conditions the Christian sipabis in the other Balkan countries had to accept after the Ottoman conquest.

$4 \quad$ Radoslav Lopašić, ed., Hrvatski urbari [=Urbaria lingua Croatica conscripta], Monumenta historico-iuridica Slavorum meridionalium, vol. 5 (Zagreb: Jugoslavenska akademija znanosti i umjetnosti, 1894), 27-81.

5 Ferdo Šišić, "Rukovet spomenika o hercegu Ivanišu Korvinu i o borbama Hrvata s Turcima" in Starine JAZU 38 (Zagreb: Jugoslavenska akademija znanosti i umjetnosti, 1937), 165, doc. 112.

6 Šišić, "Rukovet”, 245-246, doc. 188. 
It is much harder to claim anything concrete about the exchange of ideas and goods between the two sides on the border, due to paucity of relevant sources. One can only suppose that such exchanges could have happened. However, their intensity and extent was most probably not very significant, at least during the analyzed period. The trade between the two sides is, for example, much better documented for the later period of the sixteenth century, after the stabilization of borders in the 1540's, particularly the trade between the Ottomans and Venetian Dalmatia. ${ }^{7}$ The exchange of ideas between the two sides was most probably limited, as the armed conflict was the main feature of mutual relations during the analyzed period.

Contrary to all this, the migrations of population on both sides of the fluid border were very important in this and the following period. The research done for example by Ferdo Gestrin, and more recently by Lovorka Čoralić and Ivan Jurković, showed the large extent and wide geographical scope of forced migrations from Dalmatia, Croatia and Bosnia to the neighboring countries and regions, such as the Italian Adriatic coast, Istria, Austrian provinces (particularly today's Slovenia and Burgenland), etc. ${ }^{8}$ A significant number of Croatian migrants from the south populated the territories of medieval Slavonia and neighboring southern Hungarian counties in today's Croatia, among them numerous nobility, contributing to the process of gradual spreading and strengthening of Croatian ethnical, political and symbolical identity and institutions throughout these regions, too. The extent of the migration of Croatian population to safe havens, coupled with casualties in armed conflicts from the end of the $15^{\text {th }}$ century onwards, led many Croatian historians and demographers to conclude that the demographic loss in medieval Croatia during the $16^{\text {th }}$ century was almost catastrophic. On the other hand, recent research of younger Ottoman Studies scholars in Croatia, for example Kornelija Jurin Starčević, shed new light on this process from the viewpoint of the other side of the border. ${ }^{9}$ She emphasized that one must not neglect the migrations of mobile Croatian Vlach population that, during the century from the Krbava battle in 1493 and the battle of Sisak, in 1593, frequently changed sides and migrated in many occasions from the Christian territories back to the Ottoman ones. Moreover, she warned about the Ottoman sources that do not corroborate an

Tomislav Raukar, "Komunalna društva u Dalmaciji u XV st. i u prvoj polovini XVI stoljeća," Historijski zbornik 35 (1982): 75-76; idem, "Venecija i ekonomski razvoj Dalmacije u XV i XVI stoljeću," Radovi Zavoda za hrvatsku povijest 10 (1977): 221 - 223.

8 Ferdo Gestrin, "Migracije iz Dalmacije u Marke u XV i XVI stoljeću," Radovi Zavoda za hrvatsku povijest 10, n. 1: (1977): 399-400, 404; Lovorka Čoralić, "S one bane mora" - hrvatske prekojadranske migracije (XV.-XVIII. stoljeće)," Zbornik Odsjeka za povijesne znanosti Zavoda za povijesne i drustvene znanosti Hrvatske akademije znanosti i umjetnosti 21 (2003): 185, 197 198. See also footnote n. 1 .

9 See footnote n.2. 
impression about the conquered Croatian territories after 1526 as terrae desertae, how they were usually portrayed in Croatian historiography, suggesting that the repopulation of these areas started only later in the $16^{\text {th }}$ century. Namely, Ottoman defters from the beginning of the Ottoman conquest show continued presence of more or less numerous groups of autochthonous Catholic population in conquered parts of Dalmatia and Croatia.

The Ottoman-Croatian late medieval border even had its symbolic significance. How did the contemporaries on both sides primarily perceive it? The CroatianOttoman relations at that time are well researched even from the imagologycal point of view, particularly during the last few decades. Sources on both sides of the border provide a whole repertoire of images of the heathen Other, ranging from the literary topoi and negative stereotypes, including true demonization of the adversaries, till the positive stereotypes, particularly on the Christian side, praising the values of the adversaries as compared to the alleged sinfulness and moral deficiencies of the Christian defenders.

In the Croatian national imagery and in the wider public the notion antemurale christianitatis for Croatia and Croats is present even today. The centuries-long warfare on the Hungarian, Habsburg and Venetian borders with the Ottoman Empire has everything to do with that. On the other hand, during the Late Middle Ages and later this was in fact a gloomy and harsh reality for the Croatian lands and people, coupled with all possible kinds of existential threats. The antemurale metaphor in Croatian sources during that period either emphasized religious or wider cultural differences, or both at the same time. This was usually coupled with warnings to Croatia's western neighbors that they could eventually share the fate of Croatian lands if they do not assist in the common anti-Ottoman defense. ${ }^{10}$ For late medieval and early modern Croatian and Hungarian nobility the antemurale slogan became an important element of their ideological and political unity. ${ }^{11}$ However, the Hungarians and the Croats were not enjoying any exclusive position. The popes frequently used flattering titles such as antemurale in correspondence with various Christian rulers and peoples on the Ottoman borders, from the Baltic to the Black Sea and the Adriatic.

According to Ivo Žanić, from the fifteenth century onwards the antemurale motif started to be ever more present in medieval Croatian lands on three levels. ${ }^{12}$ In the narrower sense late medieval Slavonia started to be referred to as a "shield of Hungary" already from the very end of the fifteenth century. In the wider sense,

10 Davor Dukić, Sultanova djeca. Predodžbe Turaka u hrvatskoj književnosti ranog novovjekovlja (Zadar: Thema i.d., 2004), 236.

11 Ivo Žanić, "Simbolični identitet Hrvatske u trokutu "raskrižje”-"predziđe”-"most”," in Historijski mitovi na Balkanu, ed. Husnija Kamberović (Sarajevo: Institut za istoriju, 2003), 163-164.

12 Žanić, "Simbolični identitet", 165-66. 
Croatia, Slavonia and Dalmatia were also a part of East Central and South East Europe, the actual forefront of Christendom. And last but not least, members of the Croatian social elites started to identify themselves ever more as antemurale Christianitatis. Ivan Jurković, after careful analysis of relevant sources, supposed that the Croatian estates started to name themselves antemurale after the disastrous Battle of Krbava Field, in $1493 .{ }^{13}$ However, as already known, the first one who explicitly stated it in his speech in September 1522, at the Reichstag in Nuremberg, was Count Bernardin Frankapan who petitioned for help, reminding his hosts that "Croatia is a shield of Christianity" (Croatiam ipsam christianorum scutum). ${ }^{14}$ A year later, in 1523, Bernardin's son Count Krsto (Christopher) in his letter to Pope Hadrian VI (1522-1523) emphasized that Croatia is a murus ante murale of Christianity, particularly of Carinthia, Carniola, Istria, Friuli and Italy. ${ }^{15}$

The Ottoman sources of this period regarding Croatia portray events and people in terms of global holy war against the infidels, jihad, out of which this border conflict is just a small part. This can be particularly well observed in the Ottoman sources regarding the battle of Krbava Field. ${ }^{16}$ Taking all said into account, it is clear that both sides on the border still perceived their mutual conflict in essentially medieval terms of clash of religions. Ethnical and linguistic differences were of secondary importance and they were occasionally emphasized in the function of the main conflict, but they were not of primary importance. This does not mean, particularly in the Croatian case, that the conflict could not and indeed did not serve even as a catalyst of political, ethnical and linguistic homogenization among the medieval Croatian lands and people. We indeed have ample evidence of this exactly in the connection with the Ottoman menace, particularly in the texts of Dalmatian and Croatian humanists such as Marko Marulić, Juraj Šižgorić, Šimun Kožičić Benja and many others.

The paper presented here is just a brief general sketch of certain important features and processes that significantly shaped the history of this country and Southeast Europe as a whole. The border character of Dalmatia, Croatia and Slavonia remained their essential feature throughout the entire early modern period, for the following three centuries. This status and position, in turn, had their

13 Ivan Jurković, “Turska opasnost i hrvatski velikaši - knez Bernardin Frankopan i njegovo doba," Zbornik Odsjeka za povijesne znanosti Zavoda za povijesne i društvene znanosti Hrvatske akademije znanosti i umjetnosti 17, (1999): 74.

14 Bernardin Frankapan Modruški, Oratio pro Croatial Govor za Hrvatsku (1522.), eds. Ivan Jurković and Violeta Moretti (Modruš: Katedra Čakavskog sabora Modruše, 2010), 102-109.

15 Vedran Gligo, Govori protiv Turaka (Split: Logos, 1983), 356.

16 Nenad Moačanin, "Život Jakub-paše, pobjednika na Krbavi 1493.," in Krbavska bitka i njezine posljedice, ed. Dragutin Pavličević (Zagreb: Hrvatska matica iseljenika, 1997), 176; Aleksije A. Olesnicki, “Krbavski razboj po Sa'd-ud-dinu,” Nastavni vjesnik 43, (1935): 185-208, 198-99. 
profound impact as a reservoir of ideas, images, stereotypes, myths, clichés and collective (mis)representations that later became integral constituents of Croatian nationalist ideology. Is it to be expected that in today's circumstances this antemurale self-image will rise on the surface once again? Unfortunately, the recent political developments on the global, European and regional levels, point exactly to that direction.

\section{CONCLUSION}

In this paper we analyzed the period between 1458 and 1527, focused on medieval Croatia south of the Kupa and Sava rivers. This territory experienced significant demographic and economic losses during that period. Usually it is mainly perceived in Croatian historiography as a period of collapse of medieval social and economic structures, coupled with demographic catastrophe. This overall evaluation was to a certain degree strengthened through research done in the last few decades. On the other hand, several younger Croatian scholars of Ottoman studies, i. e. Kornelija Jurin Starčević, put these assumptions partly under the question mark. This analysis confirmed that in the long run, taking the whole period into account, the Ottomans significantly altered the political map of the region, coupled with radical changes in political, social, judicial and economic structures. The OttomanCroatian border was the one between the two worlds in permanent conflict of low intensity. The defense potentials of the Croats were constantly being weakened. Serious negative consequences were noticeable in central Croatia already at the end of King Matthias's reign (1490). Despite that, The Ottoman-Croatian border did not present an impenetrable obstacle to various forms of exchange of information and political negotiations. However, much less is known about the exchange of ideas and goods between the two sides, due to paucity of relevant sources. On the other hand, sources on both sides provide a whole repertoire of images of the heathen Other, ranging from the literary topo $i$ and negative stereotypes till the positive stereotypes, particularly on the Christian side about the Ottomans. During this period the notion of antemurale christianitatis became an important element of ideological and political unity of the Croatian elites. The Ottoman sources of this period regarding Croatia portray events and people in terms of global holy war against the infidels, jihad, out of which this border conflict was just a small part. Both sides still perceived their mutual conflict in essentially medieval terms of clash of religions. 


\section{BIBLIOGRAPHY}

Čoralić, Lovorka. "S one bane mora" - hrvatske prekojadranske migracije (XV.XVIII. stoljeće)," Zbornik Odsjeka za povijesne znanosti Zavoda za povijesne $i$ drustvene znanosti Hrvatske akademije znanosti $i$ umjetnost $i$ 21, (2003): 183-199.

Dukić, Davor. Sultanova djeca. Predodžbe Turaka u hrvatskoj književnosti ranog novovjekovlja. Zadar: Thema i.d., 2004.

Frankapan, Bernardin Modruški. Oratio pro Croatial Govor za Hrvatsku (1522.), eds. Ivan Jurković and Violeta Moretti. Modruš: Katedra Čakavskog sabora Modruše, 2010.

Gestrin, Ferdo. "Migracije iz Dalmacije u Marke u XV i XVI stoljeću," Radovi Zavoda za hrvatsku povijest 10, n. 1: (1977): 395-404.

Gligo, Vedran. Govori protiv Turaka. Split: Logos, 1983.

Jurin Starčević, Kornelija. "Osmanski krajiški prostor: rat i društvo u jadranskodinarskom zaleđu u 16. i 17. stoljeću." PhD diss., University of Zagreb, 2012.

Jurin Starčević, Kornelija. "Srednjodalmatinsko zaleđe za vrijeme osmanske vladavine u 16. i 17. stoljeću.” MrSc diss., University of Zagreb, 2005.

Jurin Starčević, Kornelija. "Demografska kretanja u selima srednjodalmatinskog zaleđa u 16. i početkom 17. stoljeća prema osmanskim detaljnim poreznim popisima (mufassal defterima)," Prilozi za orijentalnu filologiju 54 (2005): 139-167.

Jurković, Ivan.“Migracije. Raseljenička kriza za osmanske ugroze: “U bašćini mojoj ne dadu mi priti, «" In Vrijeme sazrijevanja, vrijeme razaranja: Hrvatske zemlje u kasnome srednjem vijeku, edited by Marija Karbić, 99-113. Zagreb: Matica hrvatska, 2019.

Jurković, Ivan. “Šesnaestostoljetna hrvatska raseljenička kriza i moderna sociološka terminologija," Društvena istraživanja 14, nos. 4-5 (2005): 759-782.

Jurković, Ivan. "Klasifikacija hrvatskih raseljenika za trajanja osmanske ugroze (od 1463. do 1593.)," Migracijske i etničke teme 19, nos. 2-3 (2003): 147-174.

Jurković, Ivan. “Turska opasnost i hrvatski velikaši - knez Bernardin Frankopan i njegovo doba." Zbornik Odsjeka za povijesne znanosti Zavoda za povijesne i društvene znanosti Hrvatske akademije znanosti i umjetnosti 17, (1999): 61-83.

Lopašić, Radoslav, ed. Hrvatski urbari [=Urbaria lingua Croatica conscripta], Monumenta historico-iuridica Slavorum meridionalium, vol. 5. Zagreb: Jugoslavenska akademija znanosti i umjetnosti, 1894. 
Moačanin, Nenad, “Život Jakub-paše, pobjednika na Krbavi 1493.," In Krbavska bitka i njezine posljedice, edited by Dragutin Pavličević, 175-77. Zagreb: Hrvatska matica iseljenika, 1997.

Olesnicki, Aleksije A. “Krbavski razboj po Sa'd-ud-dinu." Nastavni vjesnik 43, (1935): 185-208.

Raukar, Tomislav. “Komunalna društva u Dalmaciji u XV st. i u prvoj polovini XVI stoljeća." Historijski zbornik 35, (1982), 43-118.

Raukar, Tomislav. "Venecija i ekonomski razvoj Dalmacije u XV i XVI stoljeću." Radovi Zavoda za hrvatsku povijest 10, (1977): 203 - 225.

Szakály, Ferenc. "The Hungarian-Croatian Border Defense System and its Collapse," In War and Society in Late Medieval and Early Modern Hungary (War and Society in Eastern Central Europe, Vol. 3), edited by János M. Bak and Béla K. Király, 141-158. Brooklyn: Brooklyn College Press. 1982.

Šišić, Ferdo, "Rukovet spomenika o hercegu Ivanišu Korvinu i o borbama Hrvata s Turcima” In Starine JAZU 38, 157-336. Zagreb: Jugoslavenska akademija znanosti i umjetnosti, 1937.

Žanić, Ivo. "Simbolični identitet Hrvatske u trokutu 'raskrižje'-'predziđe'-'most," In Historijski mitovi na Balkanu, edited by Husnija Kamberović, 161202. Sarajevo: Institut za istoriju, 2003. 